\title{
Effects of monensin on production and energy metabolism in early lactation cows
}

\author{
Ramūnas Antanaitis, \\ Vytuolis Žilaitis, \\ Vida Juozaitienè, \\ Robertas Stoškus, \\ Mindaugas Televičius \\ Lithuanian University \\ of Health Sciences, \\ A. Mickevičiaus St. 9, LT-44307 Kaunas \\ E-mail antanaitis@lva.lt
}

The aim of the research was to investigate effects of monensin controlled-release capsules on production and metabolism in early lactation cows, with relation to the time of administration of monensin. The study was performed in 2014 (from 01/05/2014 to 01/10/2014) at a Lithuanian cattle farm having 500 dairy cows. Four experimental groups were applied as follows: 1) Group 1 (G1) control (no supplementation, $\mathrm{n}=20$ ); 2) Group 2 (G2) with supplementation of monensin (32.4 g monensin controlled-release capsule (MCRC), $\mathrm{n}=20$ ). Both groups were on 30th day before expected calving; 3) Group 3 (G3) control (no supplementation, $\mathrm{n}=10)$; 4) Group $4(\mathrm{G} 4)$ with supplementation of monensin (32.4 g monensin controlled-release capsule (MCRC), $\mathrm{n}=10)$. Both groups were on day 1 post partum. Group 2 (G2) received MCRC 30 days before calving, Group 4 (G4) 1 day after calving. Experimental and control cows received the same diet and were exposed to the same environment and management conditions during the entire experimental protocol. Blood samples were collected from the coccygeal vessels: G1 and G2 cows from day -30 (before expected calving, prior to supplementation), each day, up to 30 days post partum; G3 and G4 from day 1 post partum, each day, up to 30 days post partum. Blood serum was tested for beta-hydroxybutyrates (BHB) and glucose concentration. The daily milk yield was measured electronically (DairyPlan C21, Westfalia Surge Inc., GEA). Milk was sampled once monthly. Samples were analyzed for contents of fat, protein, lactose, urea, and somatic cells count. The BHB concentration decreased more efficiently after the supplementation of MCRC after calving. After supplementation with monensin on the first day after calving, it has been identified that the BHB concentration in serum of experimental group (G4) cows statistically significantly decreased after 3 days $(\mathrm{p}<0.05)$. During this period, the average BHB concentration of control group (G3) cows was $0.414( \pm 0.05) \mathrm{mmol} / \mathrm{l}$, while the BHB concentration of experimental group (G4) cows was $0.27( \pm 0.03) \mathrm{mmol} / \mathrm{l}$. Statistically significant differences between the experimental and the control groups were observed during the entire study $(\mathrm{p}<0.05)$.

After calving, cows supplemented with monensin showed statistically significant higher production of milk $(\mathrm{p}<0.05)$ than the control group. Statistically significant differences in the blood glucose and BHB concentration, quantity of milk and production average between two experimental groups (G2 and G4) were not identified.

Key words: cows, monensin, BHB, glucose, production

\section{INTRODUCTION}

Metabolic diseases are of great economic impact; it usually affects the animals about to reach their maximum potential production. Food consump- tion cannot be harmed in the coming days to calving and early lactation, since this is a critical period in the nutrition of females (Leilson et al., 2014). Approximately $80 \%$ of the diseases or disorders in adult cows occur during the first 100 days 
of lactation (DeGaris et al., 2010). In early lactation, dairy cows high-yielding production suffers a variety of metabolic changes derived from energy deficiency, due to poor dry matter ingestion and high milk production, which are factors that predispose to ketosis (Chapinal et al., 2011).

Basically, ketosis is the result of an imbalance between energy demand, increased fat mobilization and increased hepatic ketogenesis. Ketosis in dairy cattle frequently occurs between 2 and 7 weeks post-partum and animals can recover with or without treatment, but it results in a loss in the productive potential of each animal (Iwersen et al., 2009). Energy deficiency can be indicated by an increase in the concentrations of nonesterified fatty acids (NEFA) and beta-hydroxybutyrate (BHBA) in blood (Ospina et al., 2010).

Clinical ketosis is produced by excessive production of ketone bodies ( $\mathrm{BHB} \geq 3 \mathrm{mM}$ ) and characterized for anorexia and depression (Ospina et al., 2010). Subclinical ketosis (SCK) is an increase in the concentration of ketone bodies $(\mathrm{BHB} \geq$ $1.2 \mathrm{mM}$ ) in the absence of clinical signs (Haghighat-Jahromi et al., 2011; Sakha et al., 2007).

Adding ionophores to transition cow diets may help to modulate effects of NEB by increasing glucose availability (Petersson-Wolfe et al., 2007). Monensin (M), an ionophore, is a carboxylic polyether that is produced naturally from a Streptomyces cinnamonensis strain. Monensin alters the rumen micro-flora by selectively inhibiting the growth of gram-positive bacteria (acetate and hydrogen producers), resulting in an increase of the rumen bacteria that will increase the production of propionate, which is the primary glucose precursor (Dubuc et al., 2009).

It has not one point about the time of administration of monensin. Prepartum administration of monensin significantly increased projected 305-d milk production in cows from herds at increased risk of ketosis (Leslie et al., 1999). Treatment with monensin had no significant effect on either milk fat percentage or milk protein percentage. According to T. B. Duffield et al. (2003), monensin significantly improved indicators of energy balance in both the immediate precalving and postcalving periods, delivered in a controlled-release capsule 3 weeks precalving. According to F. D. Sauer et al. (1989), monensin is possible to administer to 3 weeks postpartum. Monensin administered for lactating cows significantly increased milk yields and milk protein (Lyncha et al., 1990). Cow treatment with monensin can reduce cost with sustaining effectiveness of treatment.

The aim of the research was to investigate effects of monensin controlled-release capsules on production and metabolism in early lactation cows, with relation to the time of administration of monensin.

\section{MATERIALS AND METHODS}

The study was performed in 2014 (from 01/05/2014 to $01 / 10 / 2014$ ) at a Lithuanian cattle farm Grinaičiai having 500 dairy cows. For the study, Lithuanian Black and White cows of 2.5 lactations and the average annual milk yield of $8100 \mathrm{~kg}$ were selected. The cows were kept in extensive environment. For the study, slow release rumen preparation, which emits approximately $335 \mathrm{mg}$ doses of monensin daily during the period of 95 days, when administered with an oral balling gun following manufacturer instructions, was used. Four experimental groups were applied as follows: 1) Group 1 (G1) control (no supplementation, $\mathrm{n}=20$ ); 2) Group 2 (G2) with supplementation of monensin (32.4 $\mathrm{g}$ monensin controlled-release capsule (MCRC), $\mathrm{n}=20$ ). Both groups were on -30 day before expected calving. Experimental (G2) and control cows (G1) received the same diet and were exposed to the same environment and management conditions during the entire experimental protocol; 3) Group 3 (G3) control (no supplementation, $\mathrm{n}=10$ ), 4) Group 4 (G4) with supplementation of monensin (32.4 g monensin controlled-release capsule (MCRC), $\mathrm{n}=10$ ). Both groups were on day 1 post partum. Experimental (G4) and control cows (G3) received the same diet and were exposed to the same environment and management conditions during the entire experimental protocol.

Group 2 (G2) received MCRC 30 days before calving, Group 4 (G4) 1 day after calving.

Blood samples were collected from the coccygeal vessels, using vacuum testing tubes without an anticoagulant (BD Vacutainer, England): G1 and $\mathrm{G} 2$ cows from day -30 (before expected calving, prior to supplementation), each day, up to 30 days post partum; G3 and G4 from day 1 post partum, each day, up to 30 days post partum. Biochemical blood tests of the cows were performed 
at the Clinical Trials Laboratory of Department of Non-Infectious Diseases, Veterinary Academy, Lithuanian University of Health Sciences. Blood serum was tested for serum beta-hydroxybutyrates $(\mathrm{BHB})$ and glucose concentration. The blood serum was measured by a computerized analyzer Hitachi 705 (Hitachi, Japan) using DiaSys (Diagnostic Systems GmbH, Germany).

All cows were milked three times daily for 100 days of the lactation phase of the trial. Daily milk yield was measured electronically (DairyPlan C21, Westfalia Surge Inc., GEA). The daily milk yield was the sum of the three milkings. Milk was sampled once monthly. The samples were analyzed for contents of fat, true protein, lactose, urea, and somatic cells count. Milk composition analysis was performed by VI Pieno Tyrimai in compliance with the approved methodologies.

Time from calving to the first insemination was recorded, and the index of insemination was calculated.

Data obtained through investigation was processed using the statistical software package SPSS (SPSS for Windows 15.0, SPSS Inc., Chicago, IL, USA, 2006). The data were considered to be statistically reliable at $\mathrm{p}<0.05$.

Research was conducted following the provisions of the Law of the Republic of Lithuania No. 11-2271 on Protection, Keeping and Use of Animals, dated 03/10/2012 (Valstybés Žinios (official gazette) No. 122-6126 dated 20/10/2012) and of the by-laws, Education and Training Purposes of Animals Used in Storage, Maintenance and Conditions of Use No. B1-866, dated 31/10/2012 (Valstybès Žinios (official gazette) No. 130-6595 dated 10/11/2012).

\section{RESULTS AND DISCUSSION}

Serum beta-hydroxybutyrate (BHB) values were insignificantly higher in G1 - $11.43 \%$ more than in G2 on Day -21 but increased significantly by day 7 (G1 100.00\% more than in G2) and remained insignificantly higher on day 30 (G1 40.00\% more than in G2) (Fig. 1).

After supplementation with monensin on the first day after calving, it has been identified that the BHB concentration in the serum of G4 cows statistically significantly decreased after 3 days ( $p<0.05$ ). During this period, the average $\mathrm{BHB}$ concentration of $\mathrm{G} 3$ cows was $0.42 \pm 0.05 \mathrm{mmol} / \mathrm{l}$, while the $\mathrm{BHB}$ concentration of $\mathrm{G} 4$ cows was $0.27 \pm 0.03 \mathrm{mmol} / \mathrm{l}$ (Fig. 2). Statistically significant difference between the experimental and the control groups was observed during the entire study $(\mathrm{p}<0.05)$.

Elevation of ketone bodies in dairy cows frequently occurs in early lactation, usually concomitantly with a lack of energy and glucose (Zarrin et al., 2013). The evaluation of NEFA and BHB represents a strategy for the monitoring of subclinical ketosis and prepartum negative energy balance in dairy cows (Contreras et al., 2010). BHBA

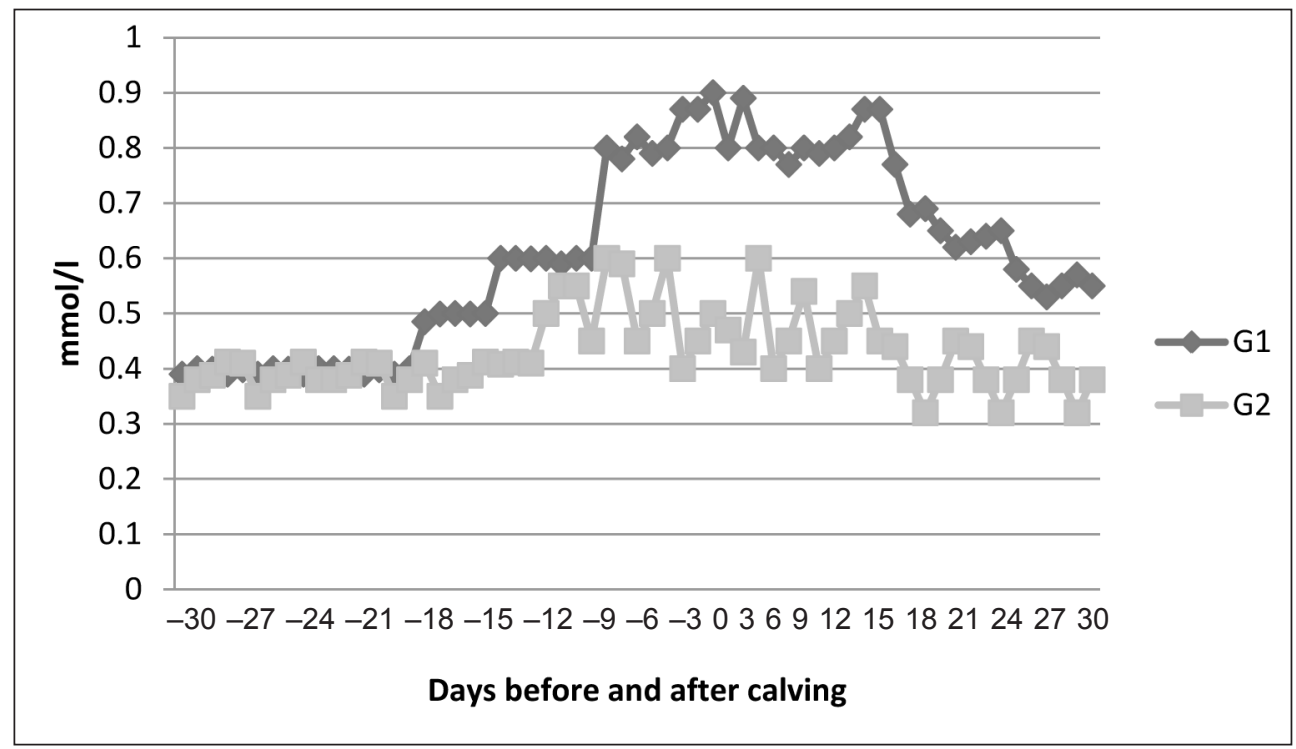

Fig. 1. BHB variation in the blood serum of Group 1 and Group 2 cows $(\mathrm{p}<0.05)$ 


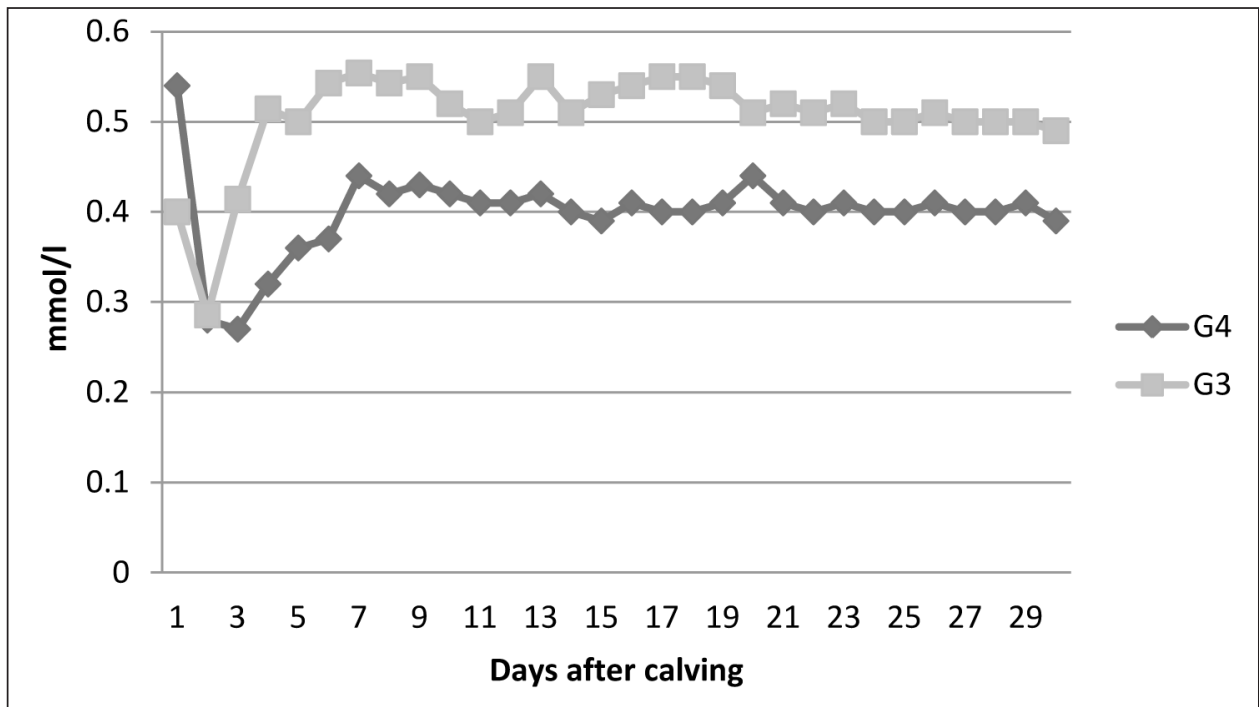

Fig. 2. BHB variation in blood serum of Group 3 and Group 4 cows $(\mathrm{p}<0.05)$

detection in blood has been used as an index to distinguish between cows with and without subclinical ketosis (Zhang et al., 2011). Subclinical ketosis can decrease economic income through decreased milk production (Oetzel et al., 2007), impaired reproductive performance (Walsh et al., 2007), increased risk of displaced abomasum, mastitis (Moyes et al., 2009) and higher risk of clinical ketosis (Iwersen et al., 2009).

The blood glucose level was insignificantly higher in cows G2 - 4.25\% more than in control cows (G1). No difference was found on day 7. Statistically reliable difference $(\mathrm{p}<0.05)$ remained on day 30 , the blood glucose level in cows G2 was observed to increase insignificantly higher $-5.11 \%$ more than in G1. Statistically significant difference of blood glucose level in the cows studied was not identified. Blood glucose concentrations in ketosis diagnosis may be an important predictor of cure of subclinical ketosis and early lactation milk production (Gordon, 2013).
A summary of the results of milk yield for cows with or without MCRC in the lactation experiment can be found in the Table.

The production average in cows G2 increased significantly higher from day 7 to day 90 (Table). There was a tendency $(p<0.05)$ for the cows with supplementation of MCRC during $100 \mathrm{~d}$ of the lactation phase to have higher milk yields - 35.03\% more than cows that were not supplemented with MCRC (Fig. 3). After calving, cows supplemented with monensin showed statistically significant higher production of milk ( $p<0.05)$ than the control group. Statistically significant differences between the two test groups (G2 and G4) were not identified. The negative impacts of subclinical ketosis on milk yield are well-known (Oetzel, 2013). J. A. A. McArt et al. (McArt et al., 2012) found that cows testing positive $(>1.2 \mathrm{mmol} / \mathrm{l} \mathrm{BHB})$ for subclinical ketosis within the first week of lactation produced $2.2 \mathrm{~kg} /$ day less milk for the first 30 days of lactation. Monensin resulted in increased milk

Table. Milk yield average of cows $(\mathrm{p}<0.05)$

\begin{tabular}{c|c|c|c|c}
\hline \multicolumn{5}{c}{ Milk yield average, kg/d. } \\
\hline \multirow{2}{*}{ Days } & $\begin{array}{c}\text { G1 } \\
\text { (without monensin) }\end{array}$ & $\begin{array}{c}\text { G2 } \\
\text { (with monensin) }\end{array}$ & $\begin{array}{c}\text { G3 } \\
\text { (whitout monensin) }\end{array}$ & $\begin{array}{c}\text { G4 } \\
\text { (with monensin after calving) }\end{array}$ \\
\hline 7 & $18.18 \pm 3.68$ & $19.34 \pm 1.87$ & $18.9 \pm 1.4$ & $19.2 \pm 1.5$ \\
\hline 30 & $23.79 \pm 4.68$ & $31.05 \pm 2.10$ & $22.89 \pm 2.1$ & $31.15 \pm 2.0$ \\
\hline 60 & $26.27 \pm 4.31$ & $33.29 \pm 2.21$ & $28.3 \pm 2.0$ & $33.4 \pm 1.5$ \\
\hline 90 & $26.92 \pm 5.47$ & $33.14 \pm 1.97$ & $27.45 \pm 2.5$ & $35.2 \pm 2.2$ \\
\hline
\end{tabular}




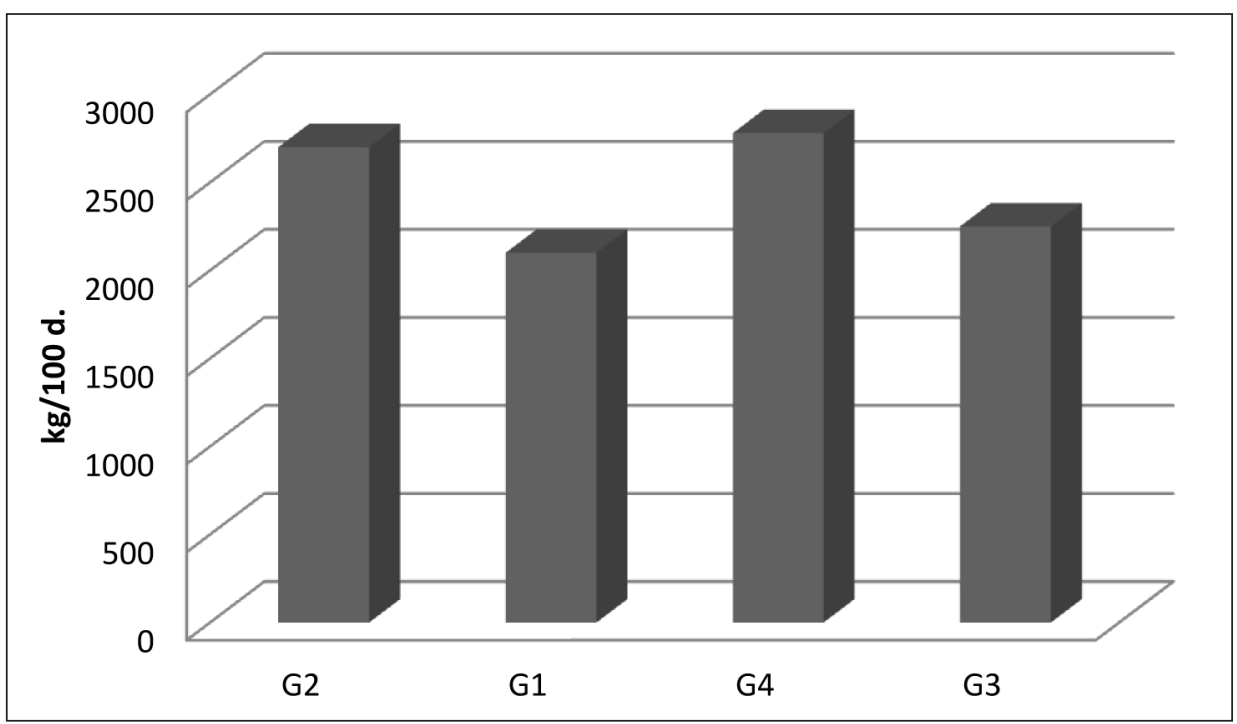

Fig. 3. Total milk yield during 100 days of lactation of Group 1 and Group 2 cows $(\mathrm{p}<0.05)$

yield (Phipps et al., 2000); while in others it caused decreased milk production (Zahra et al., 2006).

Milk fat, protein, lactose, urea, and somatic cells count $(\mathrm{p}<0.05)$ was not significantly affected by cows with supplementation of MCRC. In some trial milk fat concentrations decreased in the monensin group two weeks postpartum. There was significant heterogeneity between studies for both milk fat percentage and milk yield in animals treated with monensin (Duffield et al., 2008).

Time from calving to the first insemination and the index of insemination $(\mathrm{p}<0.05)$ were not significantly affected by cows with supplementation of MCRC.

\section{CONCLUSIONS}

Cows with supplementation of MCRC showed the following: $\mathrm{BHB}$ concentration decreases more efficiently after the supplementation of MCRC after calving. After supplementation with monensin on the first day after calving, it has been identified that the BHB concentration in the serum of G4 cows statistically significantly decreased after 3 days $(\mathrm{p}<0.05)$. During this period, the average BHB concentration of G3 cows was $0.414( \pm 0.05)$ $\mathrm{mmol} / \mathrm{l}$, while the BHB concentration of $\mathrm{G} 4$ cows was $0.27( \pm 0.03) \mathrm{mmol} / \mathrm{l}$ (Fig. 2). Statistically significant difference between the experimental and the control groups was observed during the entire study $(\mathrm{p}<0.05)$. It suggests that ketosis of cows is a possible treatment if monensin is administered after calving.

After calving, the cows supplemented with monensin showed statistically significant higher production of milk ( $\mathrm{p}<0.05)$ than the control group. Statistically significant differences in the blood glucose and BHB concentration, quantity of milk and production average between the two experimental groups (G2 and G4) were not identified.

Received 23 March 2015 Accepted 17 June 2015

\section{REFERENCES}

1. Bezerra L. R., de Oliveira Neto C. B., de Araujo M. J., Edvan R. L., de Oliveira W. D. C., Pereira F. B. 2014. Major metabolic diseases affecting cows in transition period. International Journal of Biology. Vol. 6. P. 3.

2. Chapinal N., Carson M., Duffield T. F., Capel M., Godden S., Overton M., LeBlanc S. J. 2011. The association of serum metabolites with clinical disease during the transition period. Journal of Dairy Science. Vol. 94. P. 4897-4903.

3. Contreras G. A., O’Boyle N. J., Herdt T. H., Sordillo L. M. 2010. Lipomobilization in periparturient dairy cows influences the composition of plasma nonesterified fatty acids and leukocyte phospholipid fatty acids. Journal of Dairy Science. Vol. 93. P. 2508-2516.

4. DeGaris P. J., Lean I. J., Rabiee A. R., Heuer C. 2010. Effects of increasing days of exposure to prepartum transition diets on reproduction and health in 
dairy cows. Australian Veterinary Journal. Vol. 88. P. 84-92.

5. Dubuc J., DuTremblay D., Brodeur M., Duffield T., Bagg R., Baril J., DesCoteaux L. 2009. A randomized herd-level field study of dietary interactions with monensin on milk fat percentage in dairy cows. Journal of Dairy Science. Vol. 92. P. 777-781.

6. Duffield T. F., Leslie K. E., Sandals D., Lissemore K., McBride B. W., Lumsden D. H., Dick P., Bagg R. 1999. Effect of prepartum administration of monensin in a controlled-release capsule on milk production and milk components in early lactation. Journal of Dairy Science. Vol. 82. P. 272-279.

7. Duffield T. F., LeBlanc S., Bagg R., Leslie K., Ten Hag J., Dick P. 2003. Effect of a monensin controlled release capsule on metabolic parameters in transition dairy cows. Journal of Dairy Science. Vol. 86. P. 1171-1176.

8. Duffield T. F., Rabiee A. R., Lean I. J. 2008. A meta-analysis of the impact of monensin in lactating dairy cattle. Part 2. Production effects. Journal of Dairy Science. Vol. 91. P. 1347-1360.

9. Gordon J. L. 2013. Risk Factors for and Treatment of Ketosis in Lactating Dairy Cattle. A Thesis Presented to the University of Guelph. In partial fulfillment of requirements for the degree of Doctorate of Veterinary Science in Population Medicine. Guelph, Ontario, Canada.

10. Haghighat-Jahromi M., Nahid S. 2011. Incidence of subclinical ketosis in dairy cows in Fars Province of Iran and reproductive performance in early lactation period. Asian Journal of Animal Sciences. Vol. 5. P. 158-161.

11. Iwersen M., Falkenberg U., Voigtsberger R., Forderung D., Heuwieser W. 2009. Evaluation of an electronic cowside test to detect subclinical ketosis in dairy cows. Journal of Dairy Science. Vol. 92. P. 2618-2624.

12. Leslie K. E., Duffield T. F., Sandals D., Lissemore K., McBride B. W., Lumsden J. H., Dick P., Bagg R. 1999. Effect of prepartum administration of monensin in a controlled-release capsule on milk production and milk components in early lactation. Journal of Dairy Science. Vol. 82. P. 272-279.

13. Lyncha G. A., Hunta M. E., McCutcheona S. N. 1990. A note on the effect of monensin sodium administered by intraruminal controlled-release devices on productivity of dairy cows at pasture. Animal Production. Vol. 51. P. 418-421.

14. McArt J. A. A., Nydam D. V., Oetzel G. R. 2012. Epidemiology of subclinical ketosis in early lactation dairy cattle. Journal of Dairy Science. Vol. 95. P. 5056-5066.

15. Moyes K. M., Larsen T., Friggens N. C., Drackley J. K., Ingvartsen K. L. 2009. Identification of potential markers in blood for the development of subclinical and clinical mastitis in dairy cattle at parturition and during early lactation. Journal of Dairy Science. Vol. 92. P. 5419-5428.

16. Oetzel G. R. 2007. Herd-level ketosis - diagnosis and risk factors. Dairy Herd Problem Investigation Strategies: Transition Cow Troubleshooting: Proceedings of 40th Annual Conference. Preconference Seminar 7C. American Association of Bovine Practitioners. P. 67-91.

17. Oetzel G. R. 2013. Understanding the Impact of Subclinical Ketosis. Madison: Department of Medical Sciences, University of Wisconsin.

18. Ospina P. A., Nydam D. V., Stokol T., Overton T. R. 2010. Associations of elevated nonesterified fatty acids and $\beta$-hydroxybutyrate concentrations with early lactation reproductive performance and milk production in transition dairy cattle in the northeastern United States. Journal of Dairy Science. Vol. 93. P. 1596-1603.

19. Ospina P. A., Nydam D. V., Stokol T., Overton T. R. 2010. Evaluation of nonesterified fatty acids and beta-hydroxybutyrate in transition dairy cattle in the northeastern United States: Critical thresholds for prediction of clinical diseases. Journal of Dairy Science. Vol. 93. P. 546-554.

20. Petersson-Wolfe C. S., Leslie K. E., Osborne T., McBride B. W., Bagg R., Vessie G., Dick P., Duffield T. F. 2007. Effect of monensin delivery method on dry matter intake, body condition score, and metabolic parameters in transition dairy cows. Journal of Dairy Science. Vol. 90. P. 18701879.

21. Phipps R. H., Wilkinson J. I. D., Jonker L. J., Tarrant M., Jones A. K., Hodge A. 2000. Effect of monensin on milk production of Holstein-Friesian dairy cows. Journal of Dairy Science. Vol. 83. P. 2789-2794.

22. Sakha M., Ameri M., Sharifi H., Taheri I. 2007. Bovine subclinical ketosis in dairy herds in Iran. Veterinary Research Communications. Vol. 31. P. 673-679.

23. Sauer F. D., Kramer J. K. G., Cantwell W. J. 1989. Antiketogenic effects of monensin in early lactation. Journal of Dairy Science. Vol. 72. P. 436-442.

24. Walsh R. B., Walton J. S., Kelton D. F., LeBlanc S. J., Leslie K. E., Duffield T. F. 2007. The effect of subclinical ketosis in early lactation on reproductive performance of postpartum dairy cows. Journal of Dairy Science. Vol. 90. P. 2788-2796.

25. Zahra L. C., Duffield T. F., Leslie K. E., Overton T. R., Putnam D., LeBlanc S. J. 2006. Effects of rumenprotected choline and monensin on milk production and metabolism of periparturient dairy cows. Journal of Dairy Science. Vol. 89. P. 4808-4818.

26. Zarrin M., De Matteis L., Vernay M. C., Wellnitz O., van Dorland H. A., Bruckmaier R. M. 2013. Longterm elevation of $\beta$-hydroxybutyrate in dairy cows through infusion: effects on feed intake, milk 
production, and metabolism. Journal of Dairy Science. Vol. 96. P. 2960-2972.

27. Zhang Z. G., XB Li, Wang H. B., Guo C. M., Gao L., Liu L., Gao R. F., Zhang Y., Li P., Wang Z. 2011. Concentrations of sodium, potassium, magnesi$\mathrm{um}$, and iron in the serum of dairy cows with subclinical ketosis. Biological Trace Element Research. Vol. 144. P. 525-528.

Ramūnas Antanaitis, Vytuolis Žilaitis, Vida Juozaitienè, Robertas Stoškus, Mindaugas Televičius

\section{MONENZINO POVEIKIS ŠVIEŽIAPIENIŲ KARVIŲ ENERGIJOS APYKAITAI IR PRODUKTYVUMUI}

\section{Santrauka}

Tyrimo tikslas buvo ivvertinti nuolatinio atpalaidavimo didžiojo prieskrandžio priemonès - monenzino - poveiki šviežiapienių karvių produktyvumui ir sveikatingumui, priklausomai nuo monenzino panaudojimo laiko. Tyrimas atliktas $2014 \mathrm{~m}$. gegužès 1 - spalio $1 \mathrm{~d}$. Lietuvos galvijų ūkyje, turinčiame 500 melžiamų karvių. Buvo sudarytos keturios tiriamosios grupès: I grupé (G1) - kontrolè (be papildo, $\mathrm{n}=20)$, II grupè (G2) - su monenzino papildu $(32,4 \mathrm{~g}$ monenzino nuolatinio atpalaidavimo didžiojo prieskrandžio priemone (MCRC), $\mathrm{n}=20$ ). Abiejų grupių karvès - 30 dienų prieš numatomą apsiveršiavimą. III grupe (G3) - kontrolè (be papildo, $\mathrm{n}=10$ ), IV grupè (G4) - su monenzino papildu (32,4 g monenzino nuolatinio atpalaidavimo didžiojo prieskrandžio priemonè (MCRC), $\mathrm{n}=10$ ). G2 grupei monenzino priedas buvo panaudotas likus 30 dienų iki apsiveršiavimo, G4 tas pats priedas panaudotas praèjus vienai dienai po apsiveršiavimo. Bandomosios ir kontrolinès grupių karves gavo tą patị racioną ir buvo laikomos tokiomis pačiomis sąlygomis visą bandymo laikotarpị. Kraujo mèginiai buvo imami iš uodegos venų: G1 ir G2 karvèms kiekvieną dieną nuo 30 dienos (iki numatomo veršiavimosi) iki 30 dienos po apsiveršiavimo; G3 ir G4 karvèms kiekvieną dieną nuo 1 dienos po apsiveršiavimo iki 30 dienos po apsiveršiavimo. Kraujo serume buvo ištirta beta hidroksibutiratų (BHB) ir gliukozès koncentracijos. Dienos primilžiai matuoti elektroniniu būdu (DairyPlan C21, Westfalia Surge Inc., GEA). Pieno méginiai buvo imami kartą per mènesị. Tirta: riebumas (\%), baltymingumas (\%), laktozè (\%), šlapalas (mg/\%) ir somatinių ląstelių skaičius (tūkst./ml). Nustatyta, kad BHB koncentracija labiau sumažèja panaudojus MCRC po apsiveršiavimo. Nustatyta, kad panaudojus monenziną pirmą dieną po apsiveršiavimo bandomosios grupès karvèms (G4) BHB koncentracija kraujo serume statistiškai patikimai sumažėjo po 3 dienų $(p<0,05)$. Siuo laikotarpiu BHB koncentracijos vidurkis kontrolinių karvių (G3) buvo 0,414 $( \pm 0,05)$ mmol/l, o bandomųjų karvių (G4) BHB koncentracijos vidurkis - 0,27 $( \pm 0,03) \mathrm{mmol} / \mathrm{l}$. Pastebètas statistiškai patikimas skirtumas tarp bandomųjų ir kontrolinių karvių grupių visą tiriamajij laikotarpi $(\mathrm{p}<0,05)$. Karvių, kurioms panaudotas monenzinas po apsiveršiavimo, pieno produkcija buvo statistiškai patikimai didesnè $(\mathrm{p}<0,05)$ nei kontrolinès grupès karvių. Statistiškai patikimų skirtumų tarp dviejų bandomuju grupių (G2 ir G4) nenustatyta.

Raktažodžiai: karvès, monenzinas, BHB, gliukozè, produkcija 